\title{
SOME DENTAL AND SOCIAL CONDITIONS OF 1696-1852 CONNECTED WITH ST. BRIDE'S CHURCH, FLEET STREET, LONDON
}

by

\section{WARREN HARVEY}

DURING research on the mandibular foramen, skulls of known age and sex were examined at Saint Bride's Church, Fleet Street, London, and the significance of the anatomical measurements is described elsewhere (Harvey and Robb, 1965); but, apart from these results, many aspects were revealed which induced one to get a panorama of the conditions prevailing at that time. It would have been possible, but very dull, to write prosaic descriptions with photographs of the jaws of some erstwhile parishioners of an old London church; but the story round the remains became as exciting as the findings themselves, for in it could be seen a link existing between flour, tea, coffee, cocoa, caries, sugar, smuggling, slavery, domestic silver and pottery!

\section{SAINT BRIDE OF KILDARE}

In the early days of Christianity in Ireland, Saint Patrick, Saint Brigid and Saint Columba were pre-eminent (Craig 1931). Saint Brigid was born at Faughart, now in Armagh, about the year 453. Her father was Dubtach, twelfth in descent from Fedlimidh Rochtmar, King of Ireland in the second century; her mother, Brotseach, was Dubtach's handmaid. She took the veil from Saint MacCail about the year 467, and seven virgins followed her example; she founded a religious establishment in County Westmeath and afterwards in Magh Aor. At the request of the people of Leinster she established herself at Drum Craidh; under a great oak tree she built her cell, around which were gathered the wattled huts of her community, and with Saint Conleath founded the Church of the Oak, Cil-Darra or Kildare; she died in 523. This church was probably destroyed by the Danes in 835 , rebuilt in 868 by Queen Flanna, wife of Aedh Firleath, King of Ireland, burnt in 1050 and again in 1067; Dermot O'Brien plundered Kildare Cathedral in 1136; it was in ruins again in 1615 and damaged further in the rebellion of 1641 by the Irish under Lord Castlehaven. Part of the Cathedral was restored in 1686 but the great reconstruction took place between 1871 and 1876.

ST. BRIDE'S CHURCH, FLEET STREET

All churches named after Saint Bridget were not just 'dedicated' but were foundations by herself or one of her company (Craig 1931). There was an Irish settlement in London shortly after Roman times and the church in Fleet Street was probably established in the fifth century on an earlier Christian site. The church is mentioned (London Survey Committee 1944) in a grant by Henry II to the Templars for 'forges at St. Brigide and St. Dunstans,' and later held by the Knights of St. John. It is interesting to recall that at Tully, a mile from Kildare, there was a preceptory of the 


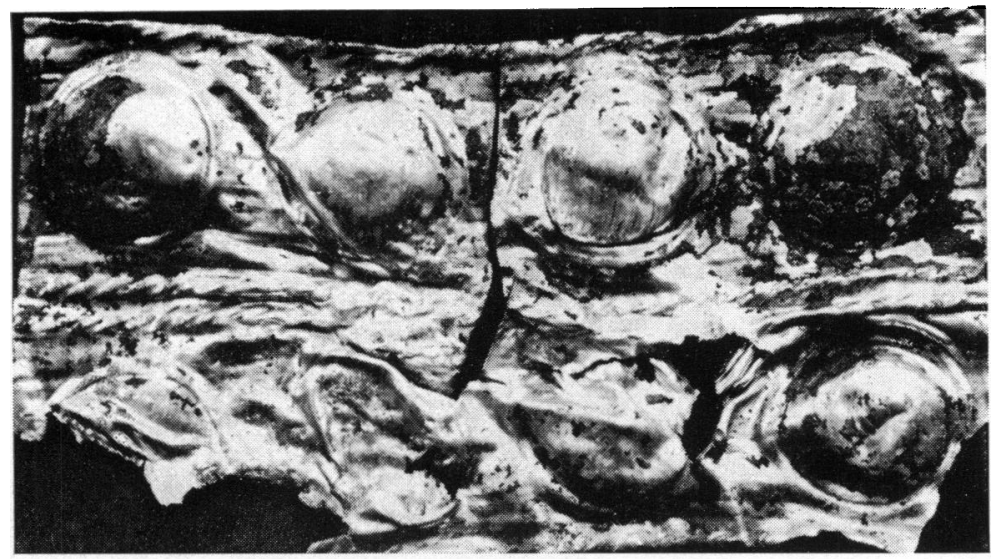

Figure 1.

Metal foil (98 per cent tin) covering an iron coffin.

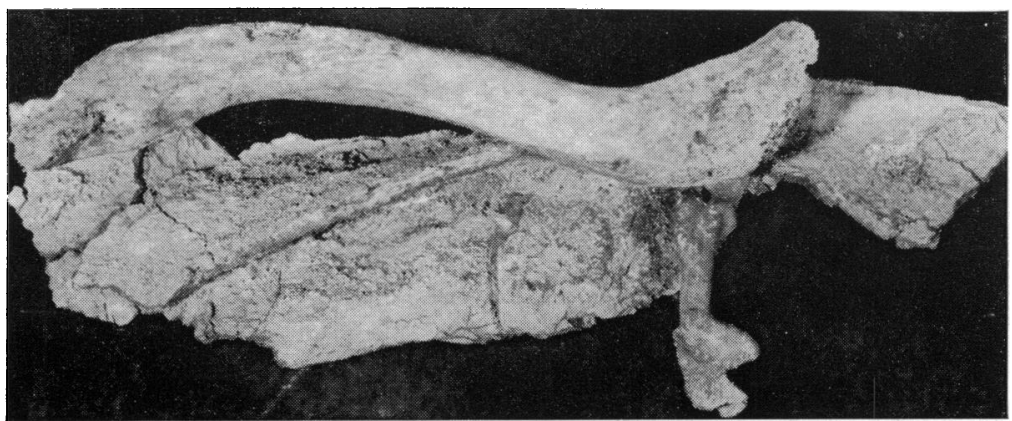

Figure 2.

The clavicle of Wynkin de Worde who was at one time assistant to William Caxton, the first English printer.

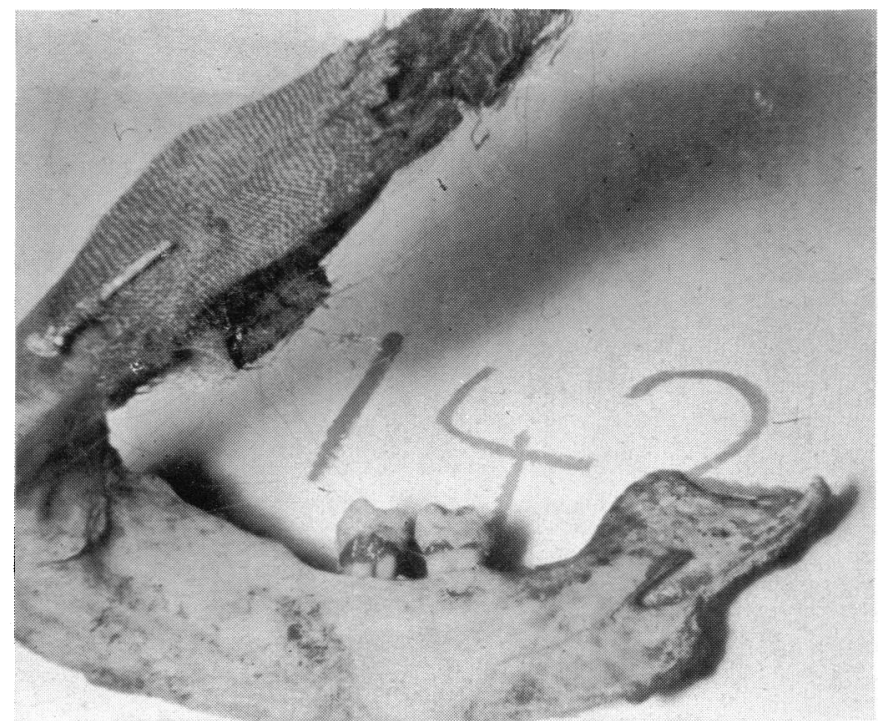

Figure 3.

Winding cloth with a pin still on the mandible of a woman aged 28 who died in 1814 . 


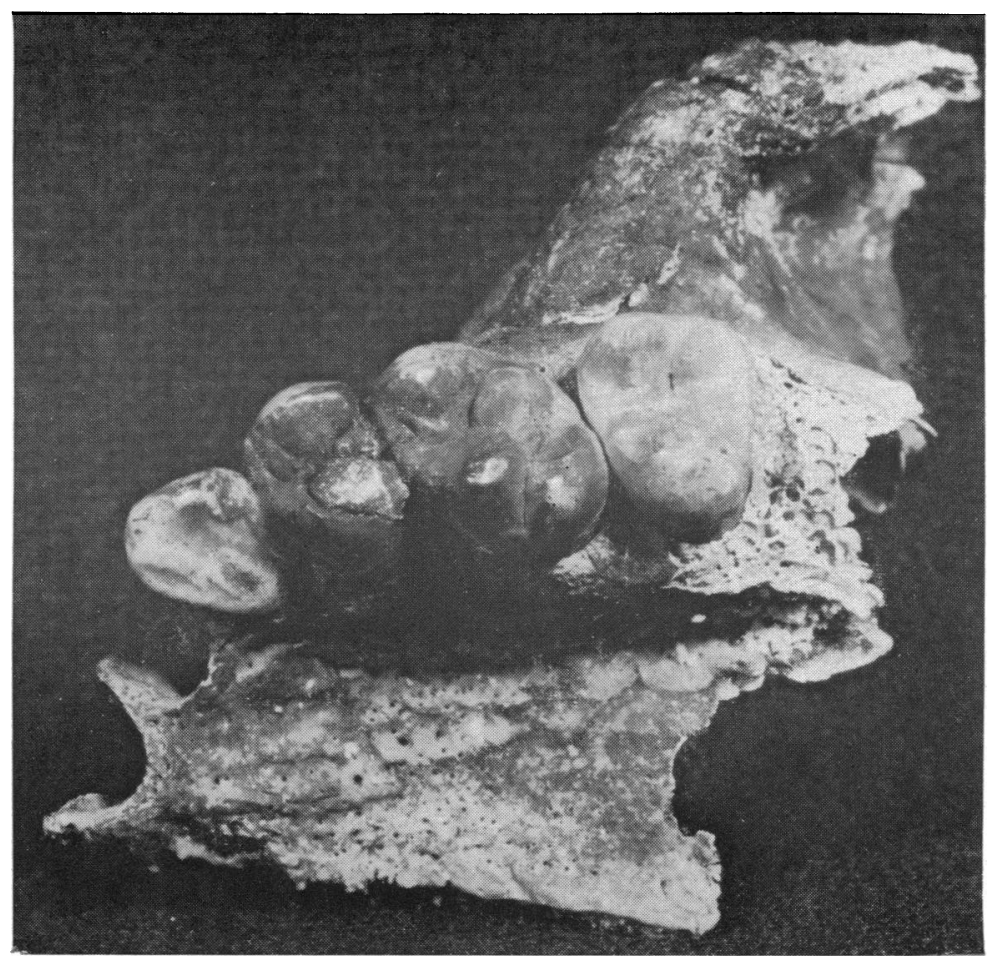

Figure 4.

Amalgam filling in a man aged 24 who died in 1848 .

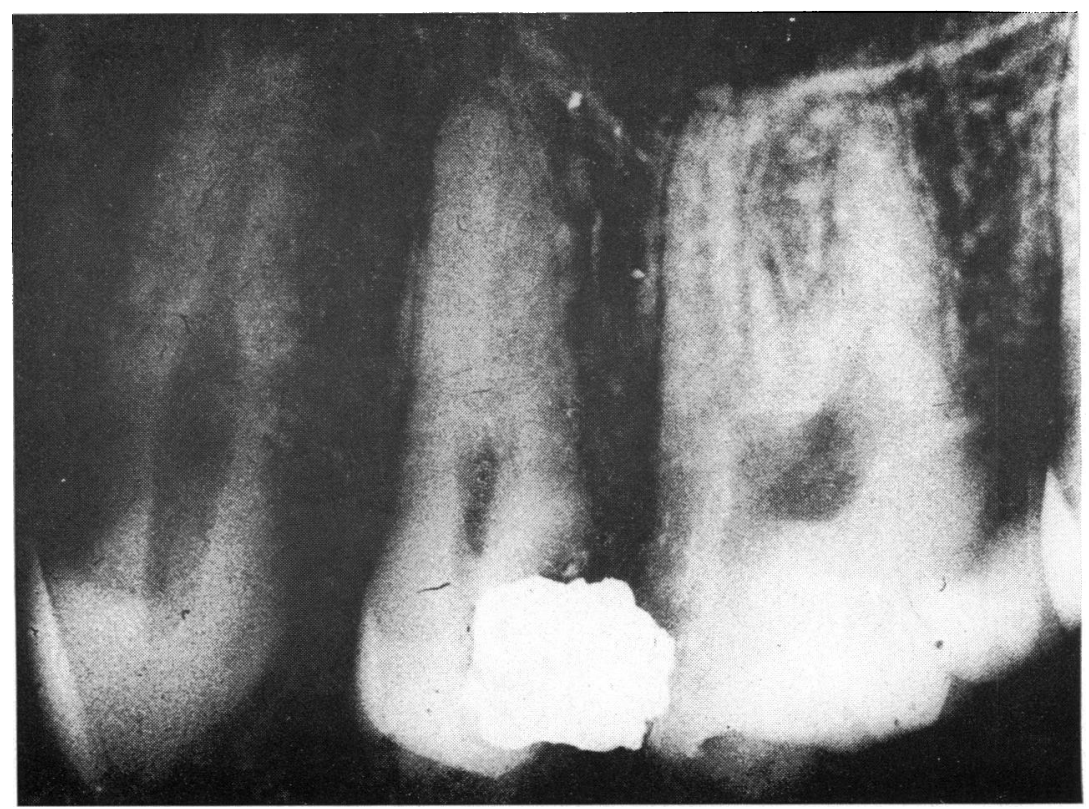

Figure 5.

Radiograph of Figure 4. It is well that the root canal has been protected by secondary dentine, for there is much shrinkage of the amalgam and cervical leakage. 


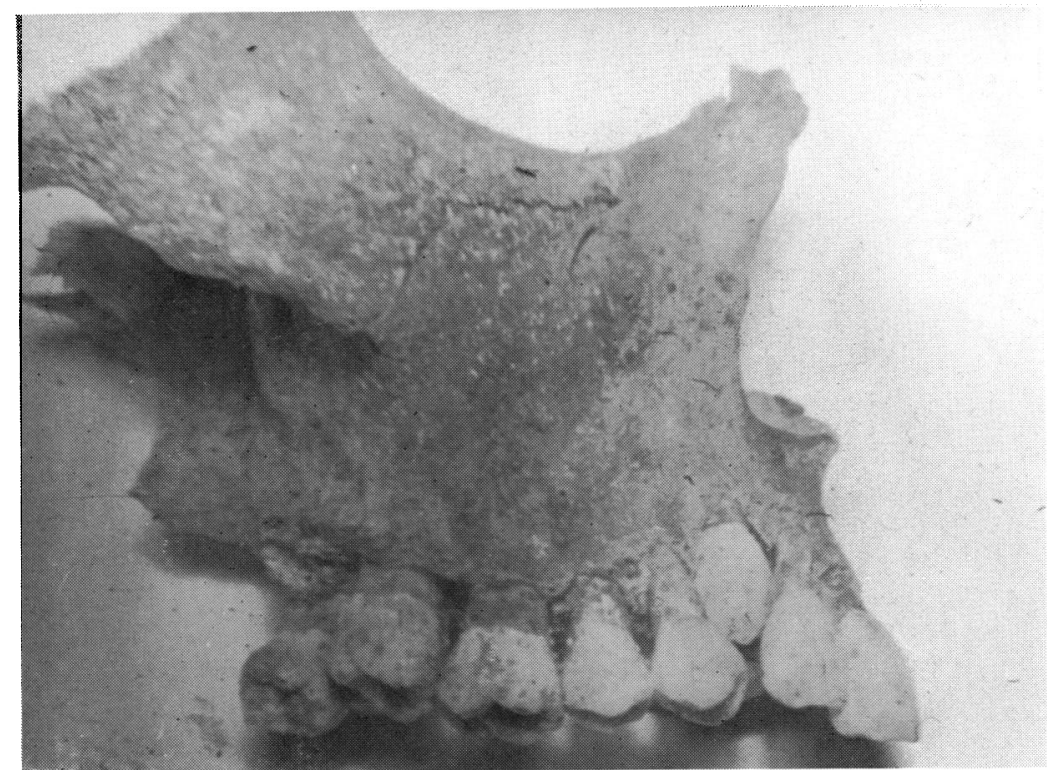

Figure 6.

Upper right canine vertically impacted and unerupted. Woman aged 42 who died in 1848 .

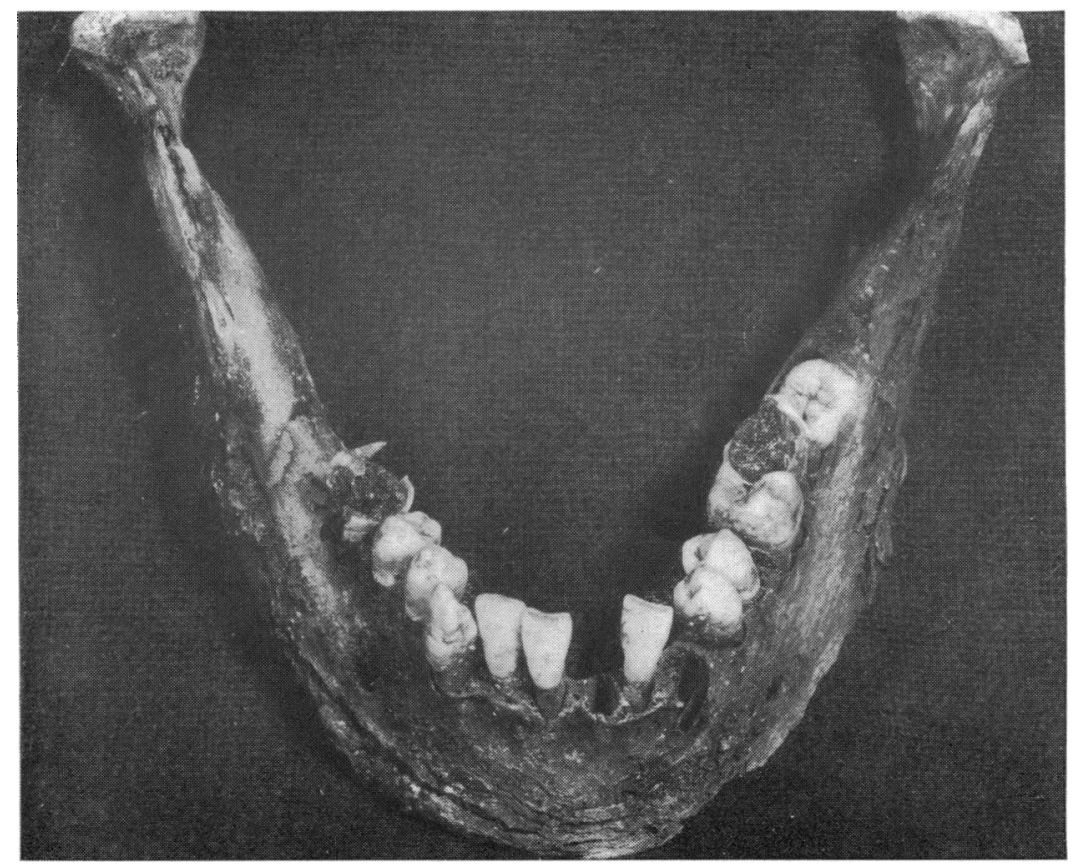

Figure 7.

Gross caries in a woman of 61 who died in 1817. 


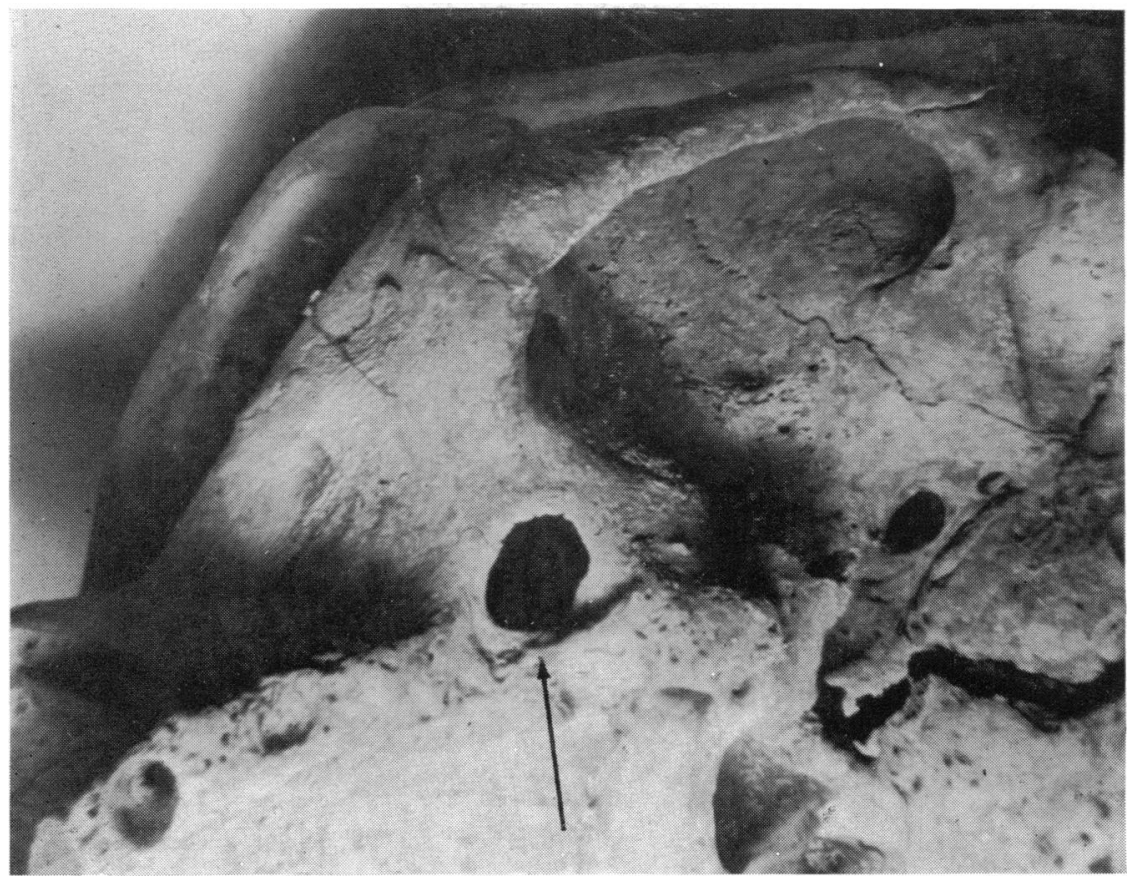

Figure 8.

Hole in right antrum in woman of 61 who died in 1852.

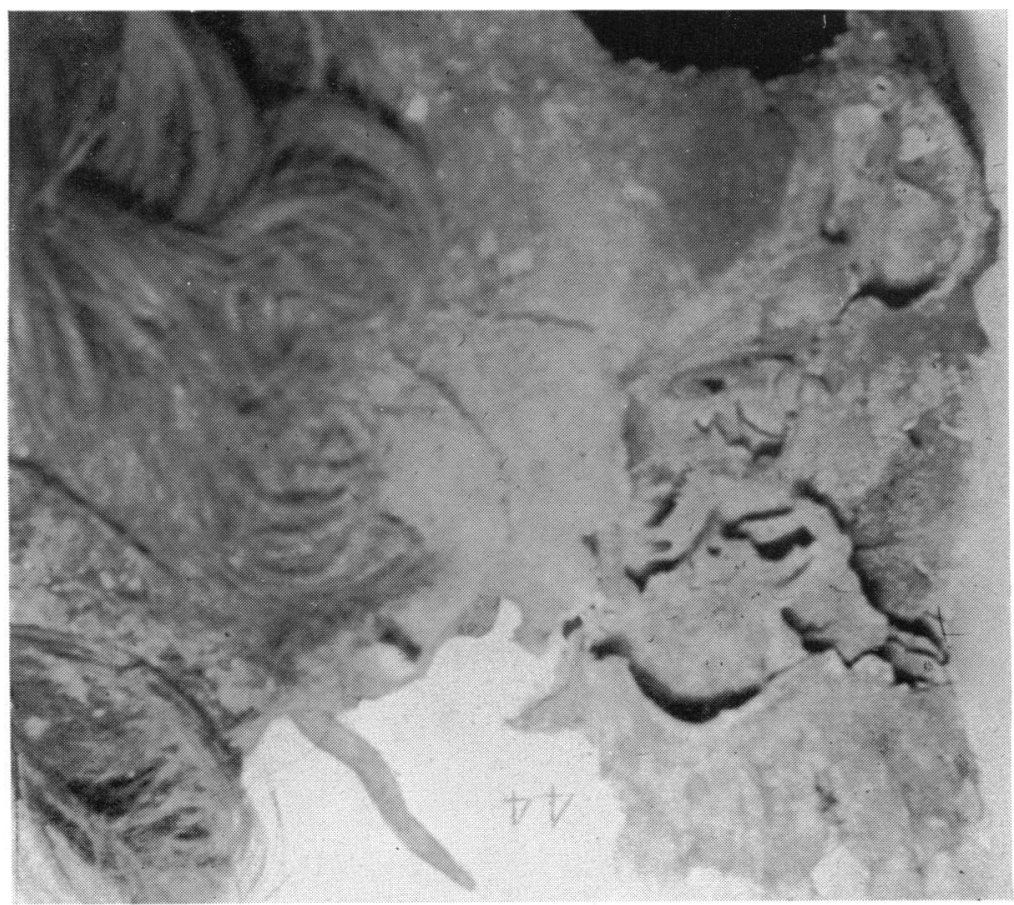

Figure 9.

Very long curly styloid in a man of 24 who died in 1849, with much hair on the skull. 


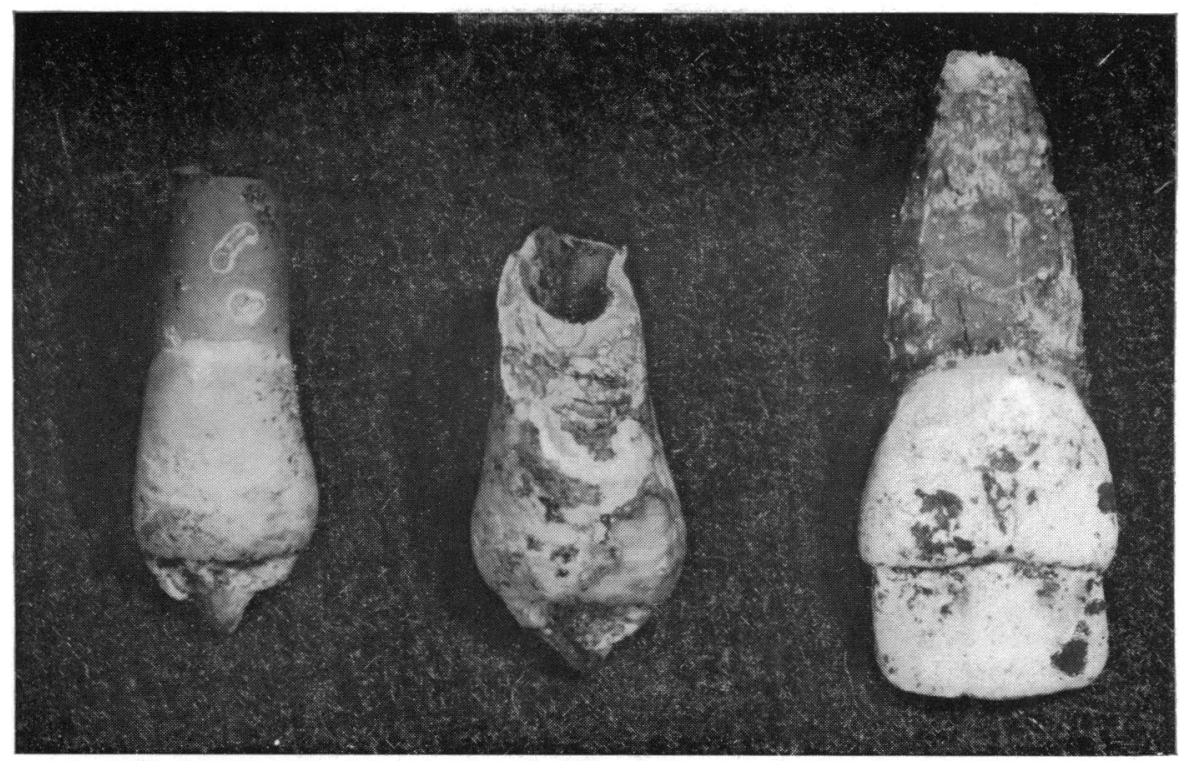

Figure 10.

Severe hypoplasia of enamel probably due to exanthematous fever superimposed on rickets.

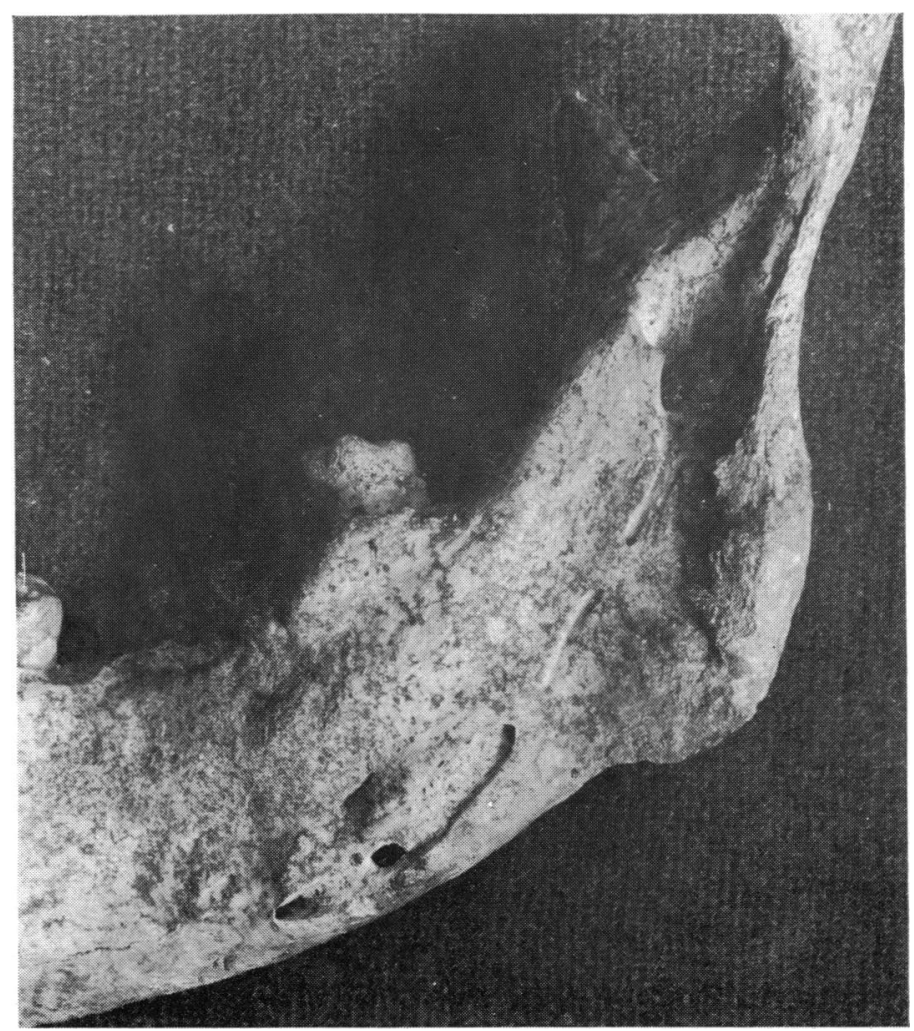

Figure 11.

The lingual surface of the mandible showing a small lingula over the foramen, with a mylohyoid groove leading from it, with a canal over the mid third; below this is the trough in which the mandibular nerve lies, pushed out on the surface of the bone. 


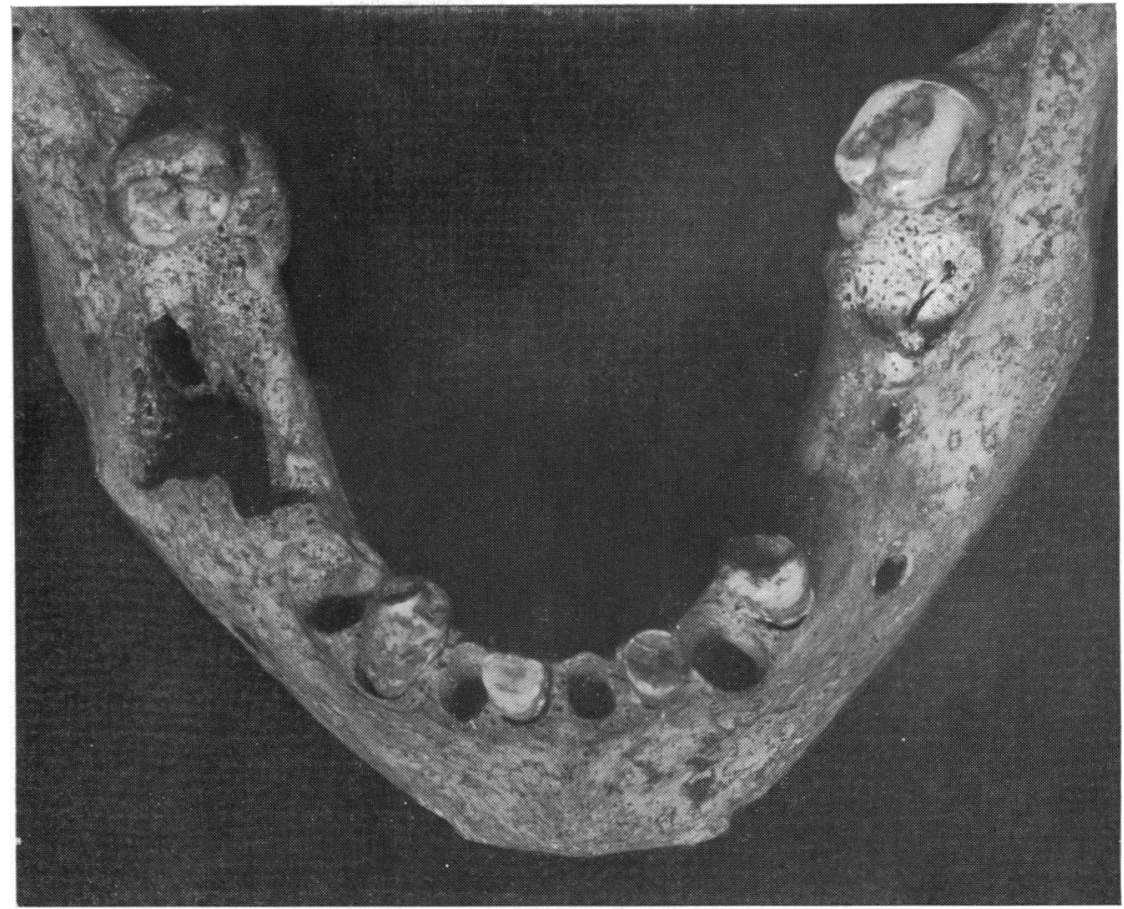

Figure 12.

Expansion of bone in the right first molar socket, with some ostaitis on the left side.

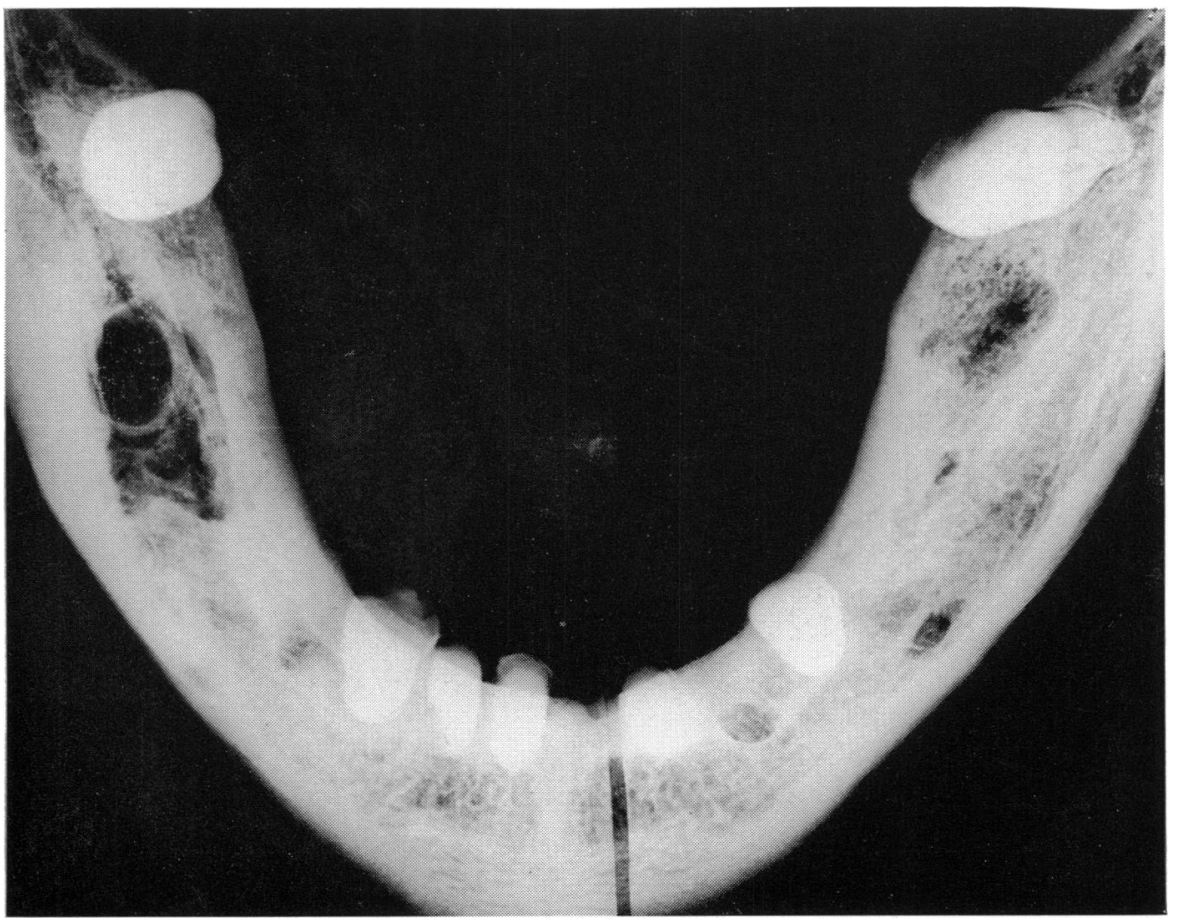

Figure 13.

Radiograph of Figure 12 showing the marked radiolucent area on the right. 


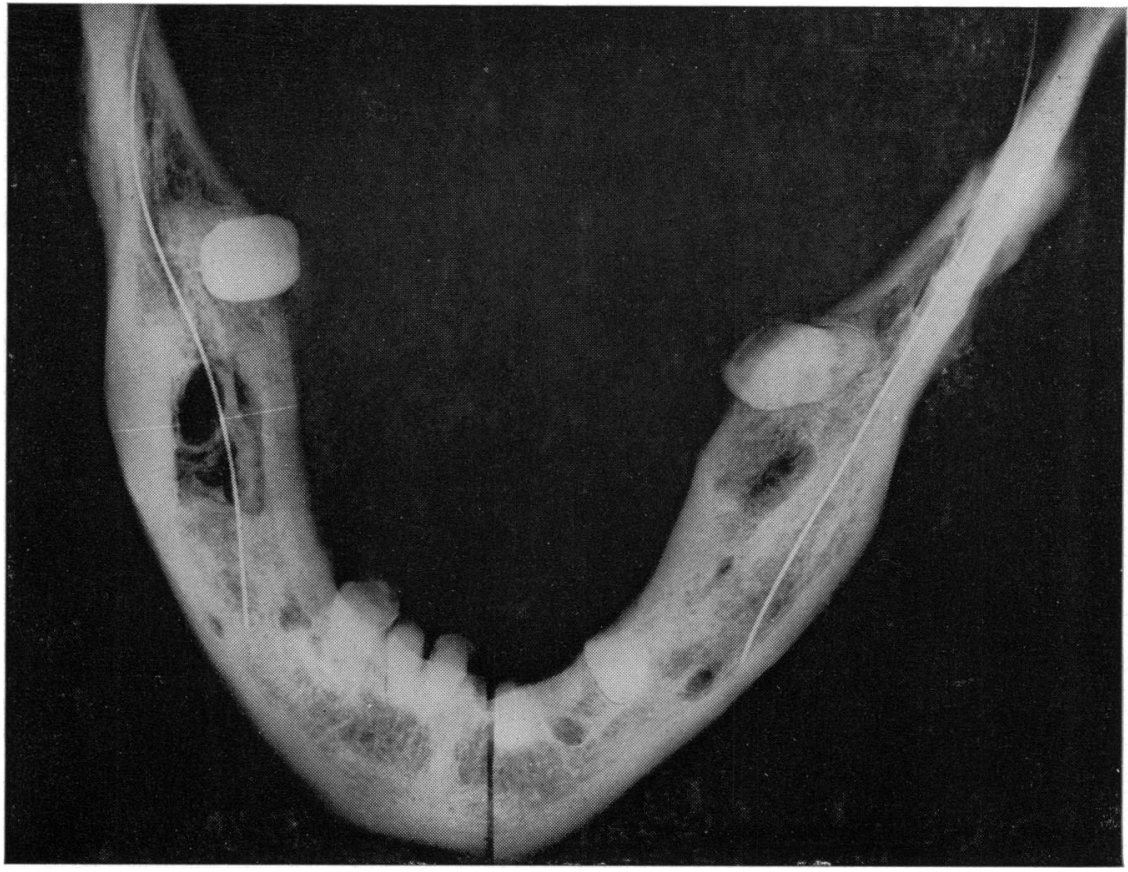

Figure 14.

Wires in the mandibular canals show how the right canal is displaced lingually on the right.

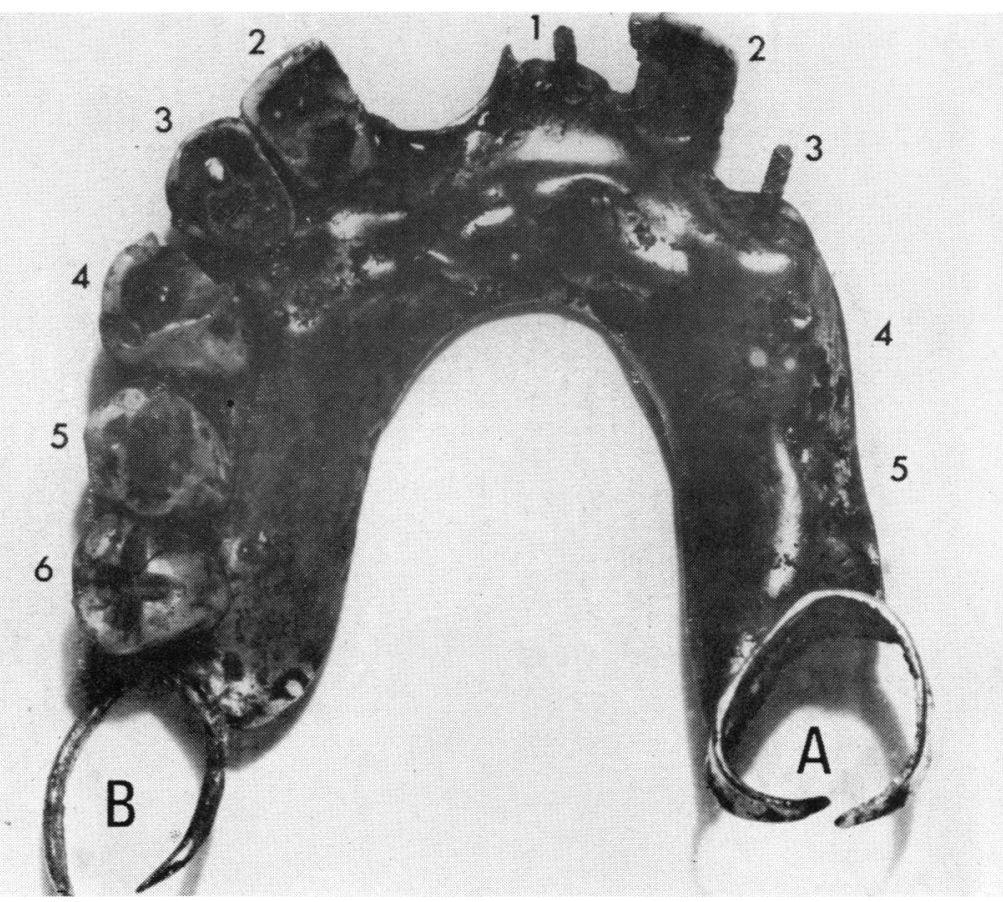

Figure 15

Gold dentures to which are attached human teeth. (see p. 66) 


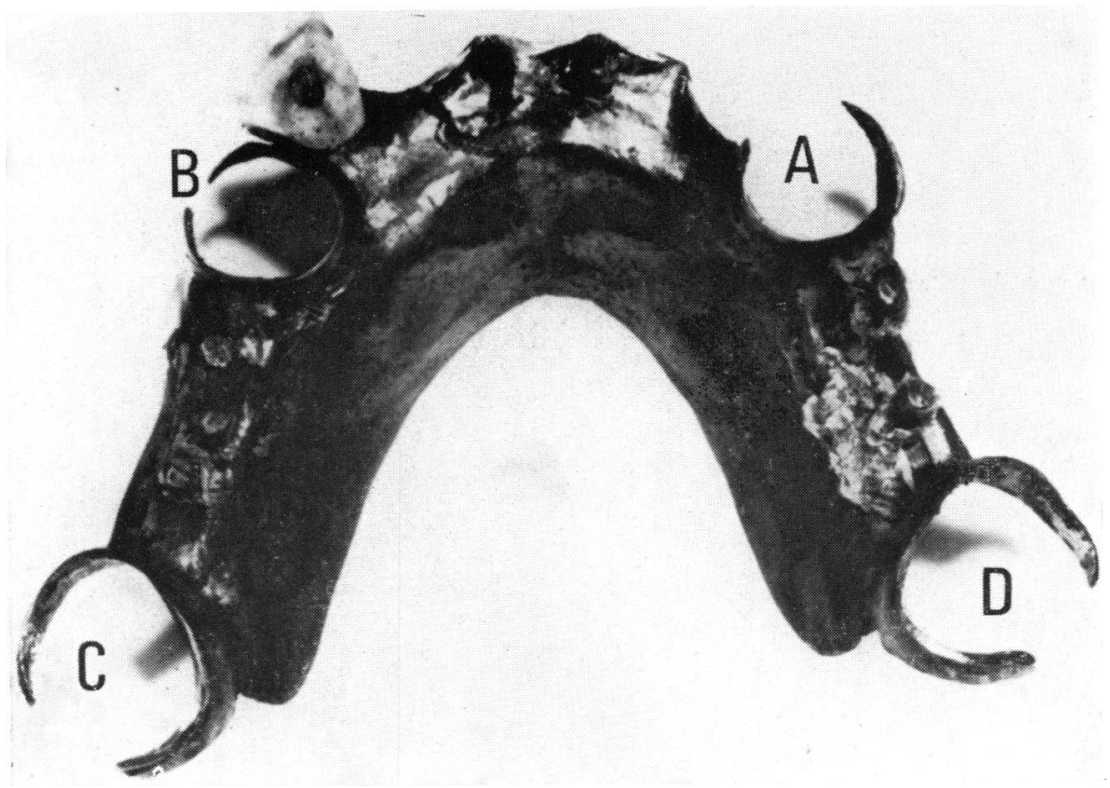

Figure 16

Gold dentures to which are attached human teeth. (see p. 66)

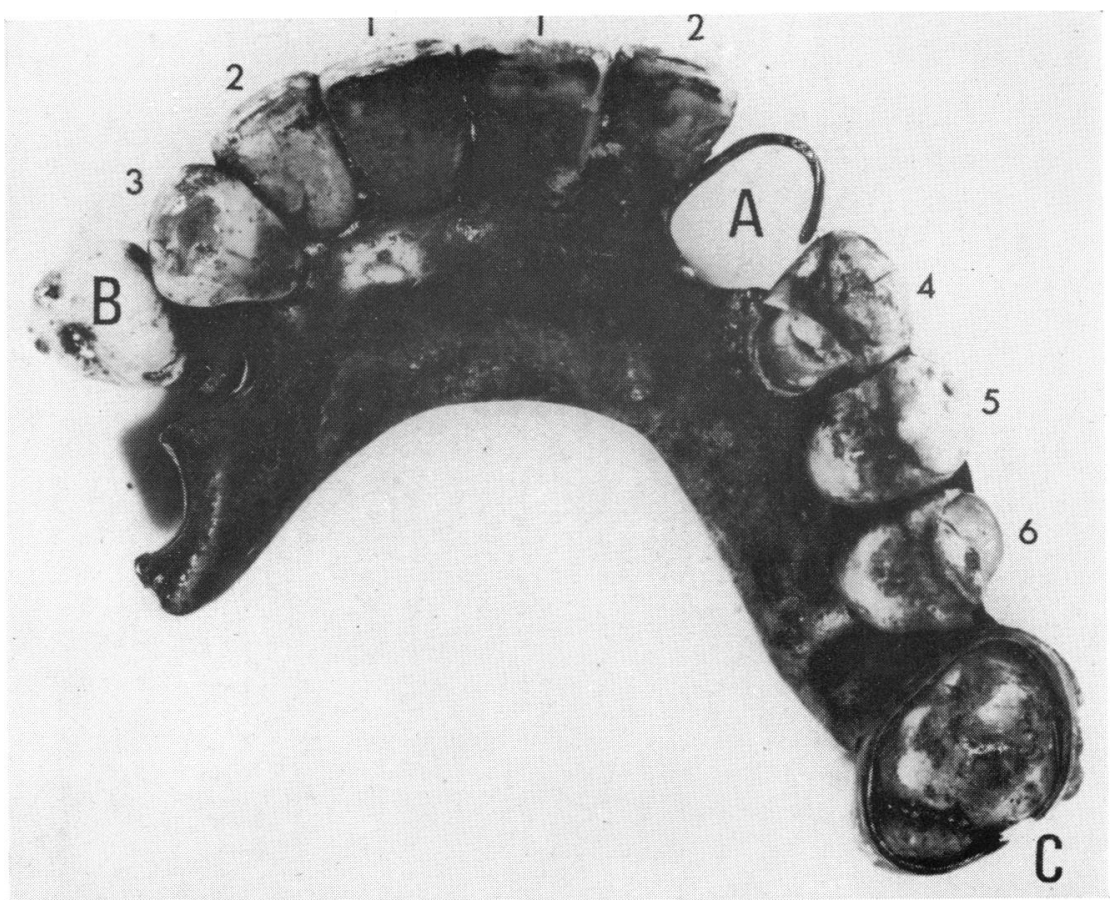

Figure 17

Gold dentures to which are attached human teeth. (see p. 66) 


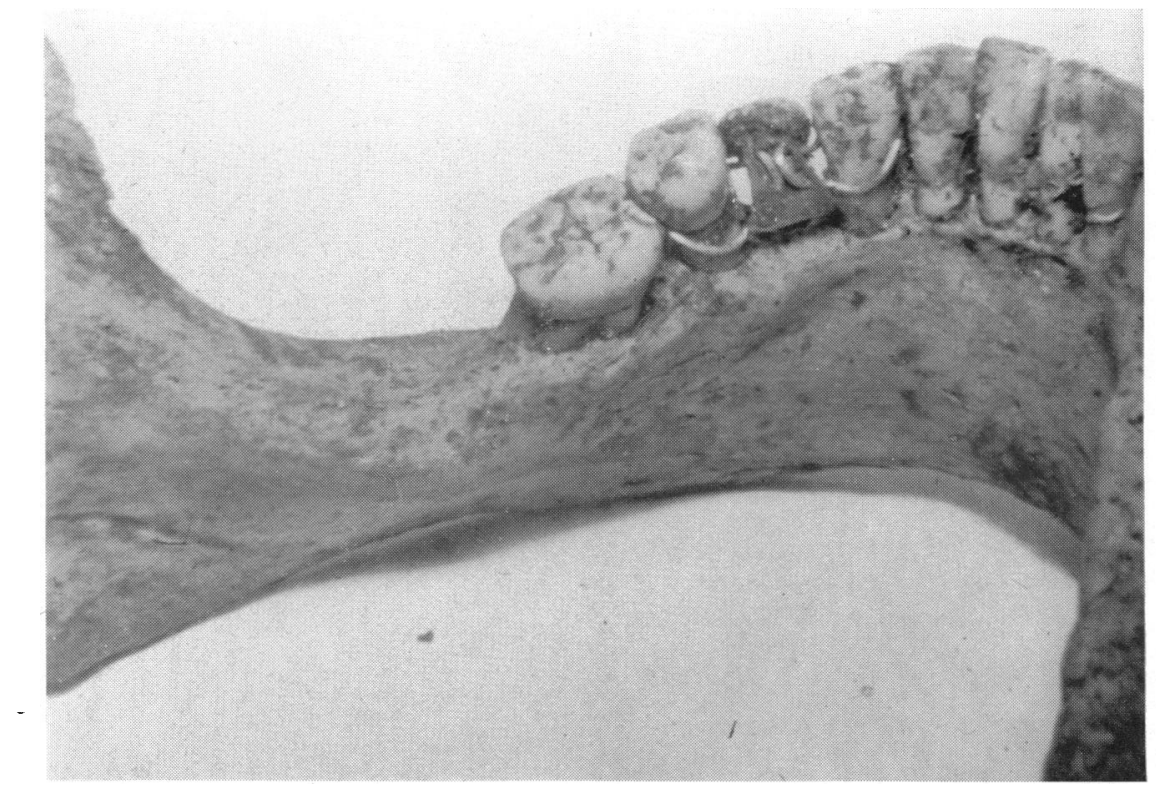

Figure 18.

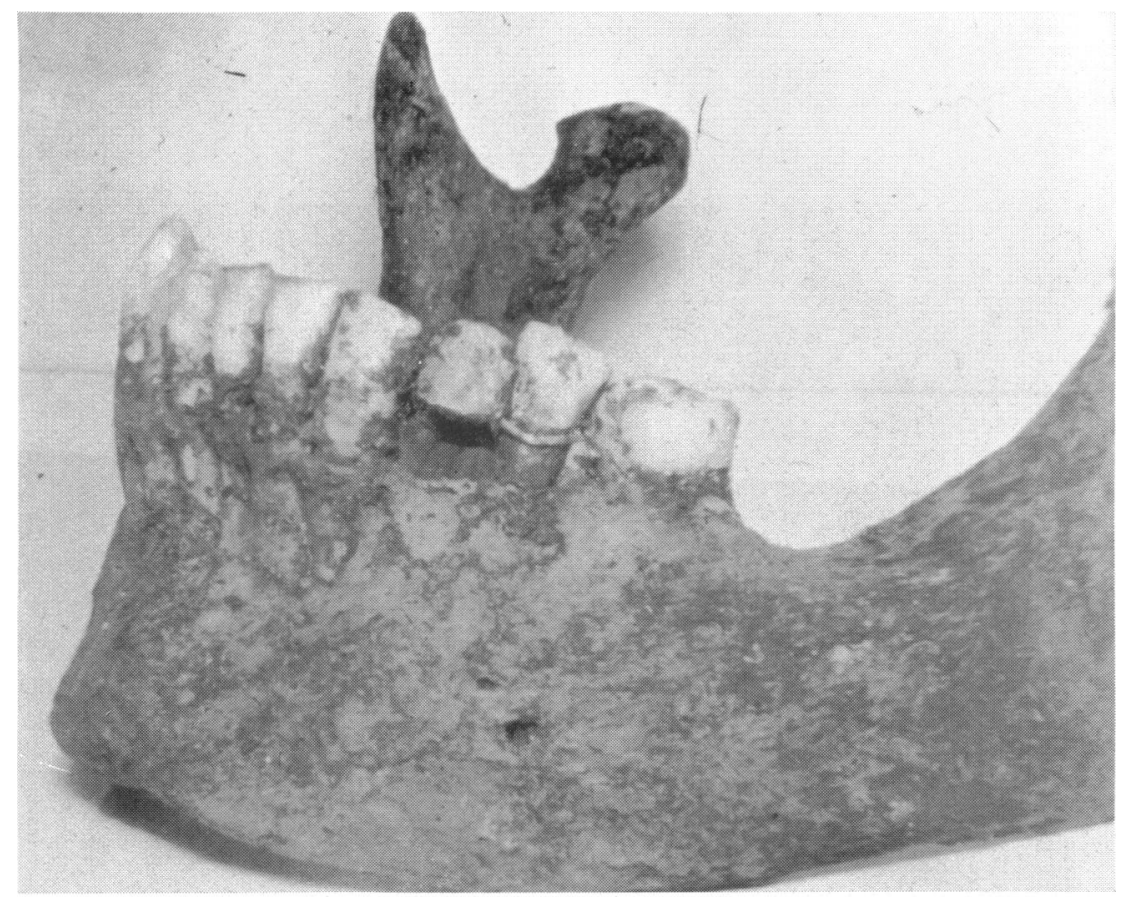

Figure 19.

Two aspects of a bridge carrying a replacement tooth, with a wire ring posteriorly and a wire rest anteriorly.

Fig. 18-from the lingual side; Fig. 19-from the buccal side. (see p. 66) 


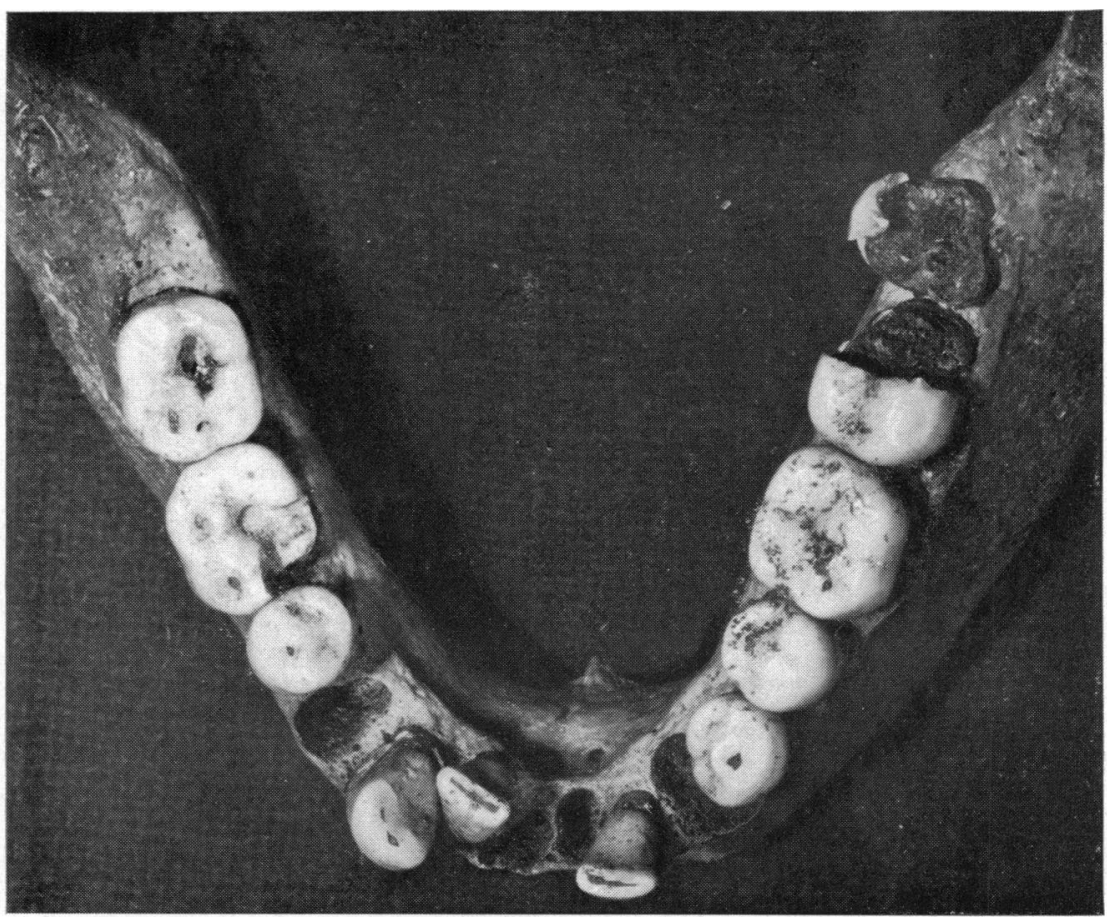

Figure 20.

Gold plug fillings in the lower right molars. (see p. 66)

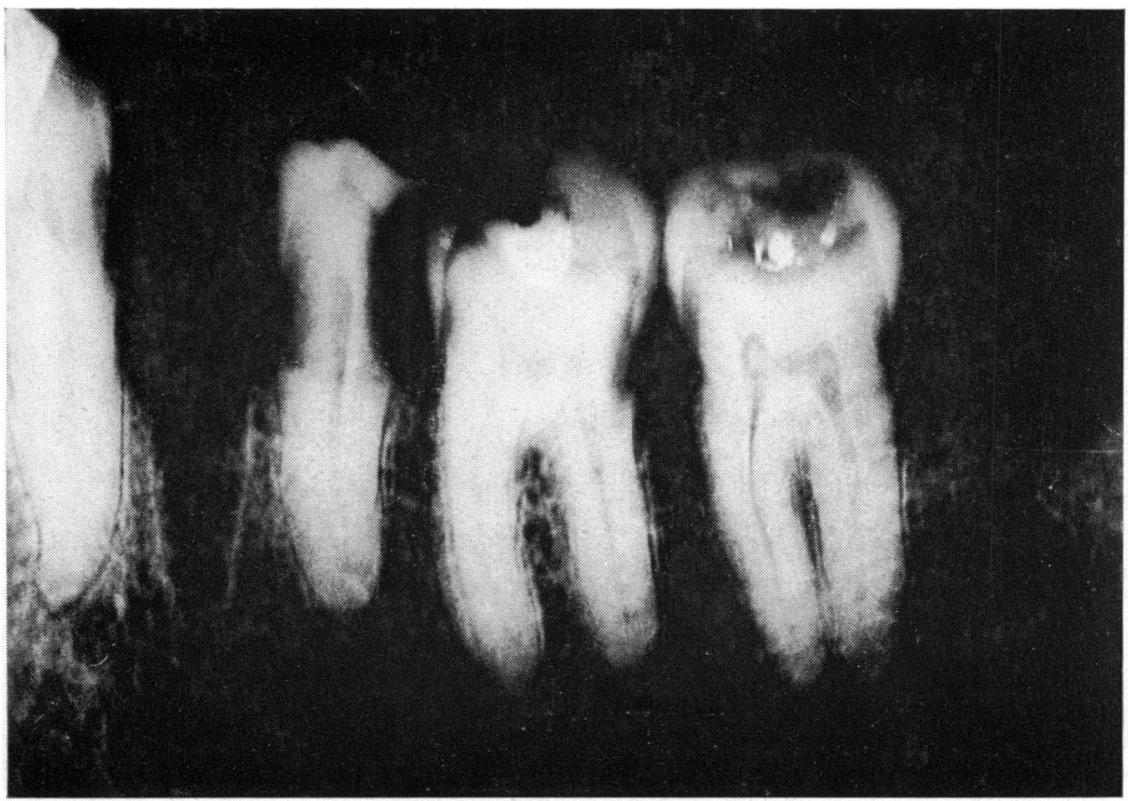

Figure 21.

Radiographs of Figure 20. 


\section{Dental and Social Conditions Connected with St. Bride's Church}

Knights Hospitallers (St. John).

The church was destroyed in the Fire of London in 1666 and rebuilt by Wren; the spire was struck by lightning in 1764, and this occasioned great controversy in the Royal Society when attempts were made to try to explain the course of the current and the $£ 3,000$ worth of damage caused; as a protection, Benjamin Franklin's new sharp pointed lightning conductor was fitted, and when the spire was again struck in 1803 , the damage was 'only $£ 500$ !'

The church was again left a smouldering ruin after a heavy air raid on 29 December 1940. And so, like St. Bridget's church in Kildare, her church in Fleet Street has also had an eventful history.

There was a legend, centuries old, that St. Bride's, Fleet Street, was built on a Roman Temple and that St. Bride's holy well was originally a shrine dedicated to a Roman god or goddess. After the bombing of 1940 the Rector and the churchwardens considered that with all the clearing up necessary, it would be a pity not to excavate the site completely, and this was entrusted to Professor W. J. Grimes who directed the work on behalf of the London Roman and Medieval Excavations Council. After two years they found the remains of a mosaic pavement, tiled wall and foundations of a Roman villa, possibly the place of worship of the first London Christians-who were Roman - and lying there was the skeleton of a Roman woman buried in the Christian way orientated east and west. To reach this level two hundred skeletons and coffins were carefully moved; the Home Office had to be consulted as to whether the remains should be buried elsewhere or cremated; Professor Wood Jones of the Royal College of Surgeons then became interested, and called in Dr. J. C. Trevor, Director of the Duckworth Laboratory, Cambridge University, who emphasized the importance of these skeletons in aiding research a century before and after the fire of London. The Chancellor of the Diocese granted a faculty to remove some of the skeletons to Cambridge for research on what Dr. Trevor described as 'outstandingly the most important collection in the world.' There had been an Order in Council in 1854 banning any further burials in City churches and the vaults had been bricked up then; however, after careful search, seven sealed vaults or crypts were found, and one which contained hundreds of skeletons can be seen with the skulls and long bones arranged as in a chess-board pattern, unique in a charnel house in this country. Altogether, from Roman and Saxon times some five thousand burials had taken place within the area enclosed by the walls of the church; plague must have accounted for many of these, and there had been epidemics in London (Bell 1957) in 1603, 1625, 1636-7 and 1640-6; the Bills of Mortality of the Dreadful Visitation of the Plague in 1665 show that the epidemic started with two deaths in April in St. Giles in the Fields, then it spread to St. Clement Danes, then St. Dunstan's, Fleet Street, and three cases at St. Bride's in June, rising to two hundred and thirty-eight cases a week there in September. About two hundred skeletons with the lead grave plates from the coffins giving their name, age and date of death were carefully preserved in plastic boxes-the first was born in 1696 and the last died in 1852. After an introduction from Dr. Trevor, the Reverend Dewi Morgan extended the hospitality of the church and his home, which eased so much the task of collecting some six thousand items of data in the six days available. 


\title{
Warren Harvey
}

THE SKELETAL MATERIAL

At first it seemed hard to understand how nearly two hundred skeletons could retain their identity, but this doubt was easily dispelled after a talk with Mr. Leonard Morgan the verger; he had carefully transferred the skeletons from the lead coffins, with the lead plates giving Christian and surnames, age (in the case of one lady there were two different plates with different ages!) and date of death, into numbered boxes, which were stored in one of the vaults; under conditions of considerable difficulty, detailed notes had been made of each skeleton as they were transferred.

St. Bride's possessed a large population of workers in the trades and crafts at the waterside; the parish records of one family suggest that they lived in great poverty, but a baronet was buried there too; the only qualification for burial at St. Bride's was probably a geographical one (Steel 1960).

In a personal communication, the verger Mr. Leonard Morgan wrote:

\begin{abstract}
We found three types of Casket: 1. Chalkestone, suggesting Saxon or earlier times. 2. Lead, with a wood interior and exterior casing; the lead casing had a name plate with very straight and ordinary lettering while immediately above this but on the outer wood casing was a more ornate plate with name, age, and dates of birth and death. 3. Iron:- of the two iron coffins the one dated 1810 had seven locks, the other was covered in very beautifully embossed foil (Figure 1). About this time the Body Snatchers were rife and it is thought that the iron coffin with the spring fastened lid was an attempt to defeat these gentlemen; there is on record a report of a law action concerning one such casket which was presented for burial at Saint Sepulchre's Church; the incumbent of that time refused to accept it on the grounds that it would occupy space in his churchyard for too long a period; the action was eventually settled by the judge who decided that the rector must accept the casket, but that he could charge a higher fee for it!
\end{abstract}

The clavicle and part of the lead coffin, considered to be that of Wynkin de Worde are shown in Figure 2; it was he who brought Caxton's printing press to Fleet Street in 1500. Some of the lead looked as if it might have been melted in one of the fires, but examination showed that this was not so, and that the sealing of the coffin had been carried out by lapping the lead sheet and then pouring molten solder over this joint.

There was an advertisement for iron coffins, together with Lord Chief Justice Abbot's views, in Wooler's British Gazette, 13 October 1822 (Turner 1932).

Body snatchers or resurrectionists were still active during the excavations and reconstruction between 1940 and 1957 . Skeletons, carefully laid out for photography, disappeared, and there were strange tales of skulls for sale locally; lead from coffins was stolen, and one man was apprehended in Croydon with a sack of 'bluey' from St. Bride's.

Some of the skeletons originally were clad in long yellow stockings, a nightshirt and a winding cloth or shroud-the pin holding the remains of the cloth round the mandible can be seen in Figure 3. Many of the skulls still had masses of long auburn hair (Figure 9)-which may persist even for thousands of years (Harrison 1963), and one skull was found to have a hair comb still in place. Many of the skulls still had earth on them and only after careful removal was it possible to see the most remarkable finding of the displaced inferior alveolar canal (Figures 11-14).

The numbers, sex and ages of the one hundred and seventy-seven skulls with intact 


\section{Dental and Social Conditions Connected with St. Bride's Church}

mandibles are shown as follows:

$\begin{array}{lccccc}\text { Age: } & 1-10 & 11-20 & 21-30 & 31-40 & 41-50 \\ \text { 92 Male: } & 6 & 4 & 11 & 11 & 11 \\ \text { 85 Female: } & 1 & 2 & 11 & 10 & 11 \\ & & & & & \\ \text { Age: } & 51-60 & 61-70 & 71-80 & 81-90 & 91-100 \\ \text { Male: } & 17 & 22 & 8 & 2 & 0 \\ \text { Female: } & 17 & 21 & 5 & 6 & 1\end{array}$

It was a surprise to find that so many had survived to the older age groups.

Although this was primarily an investigation to measure the bony relationships of the mandibular foramen in a group of known age, sex and race, other aspects of their dental condition were noted, but not in detail.

Orthodontics: One case was seen where the two maxillary first premolar teeth were absent from a woman who died in 1844 aged forty-three; in another case all four first premolars were missing from a man who died in 1835 aged forty-six; a third case was seen of a man who died in 1824 aged twenty-four where it appears that the maxillary left first premolar and maxillary left first molar were missing, and there was a metal filling in the second premolar (Figures 4 and 5).

Impactions: There was one case of a horizontal maxillary right canine in a woman aged forty-four, and another case of vertical unerupted canine in a man aged twentynine (Figure 6). Three cases of lower third molar impacted in bone were seen.

\section{PATHOLOGY}

1. Periodontal Disease: In the one hundred and seventy-seven skulls there were sixtyseven cases of obvious interdental bone loss, much of it severe, thirty-five edentulous cases, and only ten cases without loss of teeth.

2. Caries: There were only fifty-five cases where one or more teeth were standing and no caries present. Only three of the one hundred and seventy-seven cases had full dentitions without caries, and one of these had periodontal disease in the upper right third molar area. Very extensive caries could be present (Figure 7).

3. Local Conditions: The skull of a woman aged sixty-one showed perforation of the tuberosity area through to the maxillary antrum (Figure 8).

The mandible of a woman aged seventy showed a clear cut depression or fovea on the lingual surface below the molar area-Stafne's Mandibular Defect.

Though more of a curiosity than a pathological entity, the skull of one man showed a curly styloid process forty millimetres long-normally it is about twenty-five millimetres (Figure 9).

The upper central, lateral and canine of a boy aged nine who died in 1833 showed marked hypoplasia (Figure 19); this could have been due to a fever such as measles, smallpox, diphtheria or probably scarlet fever, which at this time was a child disease (Thomson 1965), between nine months and three years, with rickets throughout his life; both scurvy and rickets were endemic at this time.

The most interesting find was that seen in a mandible (Figures 11-14) of a man aged sixty-six; the bone in the right first molar region was expanded and thickened; 


\section{Warren Harvey}

when earth was gently removed from the lingual plate a groove could be seen which looked like the mandibular canal and was shown with a wire to be continuous with the mandibular foramen; later X-rays showed that the mandibular canal had been displaced so far lingually that for about two centimetres it was uncovered by any lingual bone. Two consultants (Tough and Scott Park 1965) who saw the photographs and $\mathrm{X}$-rays considered that the condition was probably due to a dental cyst with prolonged chronic infection or fibrous dysplasia, with some rarefaction of bone in a similar area on the left side of the mandible as well. Helmy (1958) and Clark (1959) both described displacement of the inferior alveolar nerve but neither mentioned extrusion of the nerve from bone, as in this case.

Dentures: In the verger's records there were notes of three gold dentures; these are in the care of Professor A. E. W. Miles, Honorary Curator of the Odontological Museum in the Royal College of Surgeons, London; most kindly he gave me the following descriptions and photographs (Figures 15, 16, 17). 'The dentures have a remarkably modern appearance, apart from the natural teeth in place of porcelain ones; they clearly resemble the swaged gold dentures we had to construct as students.' Figure 15: Female aged sixty died 1832.

65432 human teeth fixed on posts which show on the palatal surfaces. 13 bare posts. 2 human tooth on post. 45 two stumps of posts. A is a plate clasp, B is a wire clasp. Figure 16: Female aged twenty-four died 1818.

$2\rfloor$ is a human lateral tooth on a post. 45 are a pair of posts with linen thread on them-before cement and sulphur were used, linen was wound round the posts and the teeth pushed on; the linen became wet, swelled and held the teeth firmly on. ABCD are plate clasps soldered on to the gold base.

Figure 17: Female aged seventy-one died 1840.

321 12 are natural human teeth apparently fixed to the gold denture but the posts cannot be seen. 456 are human premolar teeth. A and B are wire clasps, C is a plate clasp; two of the owners' teeth are in their respective clasps 'B and C.'

Bridgework: On the mandible of a female aged fifty-five who died in 1836, the missing left first premolar is replaced by a ring of gold wire round the second premolar, carrying what appears to be a porcelain 'tooth' with a gold wire rest on the canine (Figures 18 and 19).

Fillings: Gold plugs (Figures 20 and 21) were seen in two men both aged fifty-nine who died in 1820 and 1834 respectively; gold plugs were also seen in the teeth of two young women aged eighteen and twenty-three who died in 1820 and 1825 respectively.

In a man aged twenty-four who died in 1824, a distal occlusal metal filling was seen in the maxillary left first premolar-the second premolar was missing (Figures 4 and 5); there was definite staining of adjacent maxillary teeth and the mandibular teeth met on occlusal contact. Analysis of the metal filling showed that its composition was silver 46.0 per cent, mercury 53.0 per cent, iron 0.07 per cent, copper 0.02 per cent; Dr. Howard Worner, the consultant metallurgist, expressed doubt that this filling could have been made from filings of a coin. The Master of the Royal Mint kindly confirmed this suspicion, for he gave the information that United Kingdom silver coins made between 1583 and 1919 contained 7.5 per cent copper, and there were no pure silver French coins of this period from 1833, when this filled premolar could 


\section{Dental and Social Conditions Connected with St. Bride's Church}

have erupted, to 1848 when the young man died; this filling must have been made from filings of pure silver. Radiographs taken of this amalgam filling (Figure 5) showed some radio-opacity of the floor of the cavity; it was thought that this might possibly be due to treatment by cautery or zinc oxychloride, spirits of ammonia, sulphuric or nitric acids, or silver nitrate-all of these were treatments in use between 1833 and 1848. However the X-ray diffraction pattern of this hard brittle material from the floor of the cavity was similar to that of normal dentine.

SOCIAL CONDITIONS 1693-1852

Although no effort was made to collect figures for a reliable caries index, it was abundantly obvious that both periodontal disease and caries were rampant during this period. Brothwell (1959) has commented on the prevalence of caries in this period. In his excellent review of diet in relation to caries Hardwick (1960) covered a wide field; however it was felt that it would be of great interest to look more closely at the way of life of these people who lived between 1696 and 1852.

The seventeenth century saw the establishment of country estates by those who made fortunes in the great trading ventures like the East India Company; this resulted in more land coming under cultivation, more corn and less wool, more wheat and less rye. A spate of books appeared on agriculture and gardening. Towards the end of the century turnips from Holland were being grown extensively, and clover, with tremendous benefit to the winter feeding of cattle. (Drummond and Wilbraham 1958). Potatoes were being grown, though mostly in the north, also more herbs and vegetables. Strawberries, damsons, currants and gooseberries were introduced; vines, peaches, nectarines, oranges and lemons were grown in heated greenhouses. Pike, carp, bream and tench were stocked in fish ponds. Pigeons and venison were important winter foods, with rabbits whenever they could be shot or poached. There was a series of bad harvests between 1693 and 1699, and although it was blithely said that no common people in the world were better fed and clothed, more at ease and propagated faster than in Britain, yet conditions were so bad that people were even emigrating to Ireland! (Davidson et al., 1959) The poor ate bread, beef, beer and cheese mostly; dark rye and bran breads were less popular in London than white wholemeal bread; much beer was drunk-St. Bartholomew's Hospital allowed each patient over twenty pints a week, for it was much safer to drink than water, and children drank it too. It was not unusual for very old people and invalids to be provided with wet nurses, or asses' milk as an alternative.

Flatulence seems to have been quite a problem, for Burton listed sixty-four herbs or simples to expel the wind. Stone in the urinary tract or bladder was much more common in the rich; the poor ate more butter and probably got more vitamin $\mathbf{A}$; this vitamin lack may also account for the numerous remedies for 'clearing the eyesight', such as fennel, parsley and liver, but grim folklore persisted in the use of powdered human excreta blown into the eyes. As with all communities that eat much meat, constipation was another problem for the rich, who would resort to senna, rhubarb or dandelion; evils of the mind and body were still thought to be expurgated through the bowels, and this is best exemplified by Louis XIII of France who owned a beautiful collection of porcelain, gilded silver and mother of pearl enema syringes 


\section{Warren Harvey}

with which in a year his doctors are reputed to have administered two hundred and ten enemas in addition to two hundred and fifteen purgations!

For the first fifty years of the eighteenth century England was prosperous so that food, fabrics, and candles were cheap; villagers had smallholdings and gardens, while townsmen had plenty of meat. In Queen Anne's reign only about 15,000 acres covered by two Acts of Enclosures were taken, but in George III's reign over three million acres were 'filched from the people', and shattered once and for all the simple economic structure of English village life. Small farms were swallowed up by bigger farms to improve agriculture, and a series of poor harvests from 1764 to 1775 crippled the poor but helped the big farmers and landowners because of high prices; this is the basis of Oliver Goldsmith's Deserted Village written in 1769. This Desolation of the Villages was followed by the Highlands and Islands Clearances early in the nineteenth century. For sixty years the country was at war-Clive won Plessy in 1757, Wolfe won Quebec two years later, then came the Boston 'tea party' in 1773 and the American Declaration of Independence in 1776; in 1778 there was war with France, joined two years later by Holland and Spain, while Nelson won Trafalgar in 1805 and Wellington won Waterloo in 1815. All this must have meant a tremendous strain on the economy and living conditions of the country. Country folk moved to towns whose rapid growth revealed the inadequacy of transport; the Duke of Bridgewater (Sampson Low 1957) commissioned James Brindley to build canals in 1758; the Turnpike Acts of George III enabled some improvement to be made on the roads, but it was really Metcalfe, Macadam and Telford who introduced modern roads; from James Watt's steam engine in 1769, invention and application evolved through many men the railways of the early 19th century. Vegetables for the Spitalfields Market came from Lewisham and Blackheath, while potato farms were run by Irish labourers at Wanstead and Ilford. Meat came from as far as Yorkshire and North Wales-cattle from Anglesey swam the Menai Straits to Abergale Fair, on to Barnet Fair, and then were fattened for Saint James's, Newgate and Leadenhall markets. White bread had been available as a luxury for two thousand years, though mostly stone ground dark rye or wholemeal flour was used. But now even in times of shortage, townspeople would only eat fine wheaten bread, though there were times when the Standard bread contained rye, barley, oats, and potatoes, with many more 'adulterants' in later years.

Rickets and scurvy were rampant, and among the many remedies for loosened teeth there was recommended 'scurvy grass or gittings to put in the childrens' ale.'

Because they went 'off' so quickly, milk and mackerel could be sold or 'cried' in the streets before $9.0 \mathrm{a} . \mathrm{m}$. and after $4.0 \mathrm{p}$.m. Oysters were still plentiful and were sold with gingerbread on barrows. The best milk in London was from the cows grazing in St. James's Park; whey and buttermilk were also sold in the streets. It is a grim thought that the barges which brought vegetables into London, returned to the market gardens with the night soil contents of the cesspools.

Chocolate only became well known in England after 1650, and in Queen Anne's reign it was the favourite drink of the aristocracy, costing about fifteen shillings a pound; one of the first chocolate houses was run by a Frenchman in Queen's Head Alley off Bishopsgate Street in 1657. In 1824 John Cadbury set up as a tea and 


\section{Dental and Social Conditions Connected with St. Bride's Church}

chocolate dealer, but not until 1853 when the import tax was reduced, were cocoa and chocolate brought within the reach of ordinary people.

The first coffee house in London was opened in St. Michael's Alley off Cornhill in 1652 and was called the Pasqua's Head; coffee houses soon became the meeting place for friends (men only) and where business was often conducted. There was Lloyd's coffee house in Lombard Street for shipping news, Jonathan's in Change Alley for Stockbrokers, London Coffee house for estate agents, Tom's in Devereux Court, and Will's between Covent Garden and Bow Street as a literary centre; however, it was in the Turk's Head that Samuel Johnson founded his Literary Club and met Oliver Goldsmith, David Garrick and Sir Joshua Reynolds-with James Boswell busy making notes. The Rape of the Lock was written by Pope from coffee house gossip, but he also wrote 'Here thou, great Anna, whom two realms obey, Dost sometimes council take and sometimes tea.' At one time there were over two thousand coffee houses in London. In the 1730s Old Slaughter's Coffee House in St. Martin's Lane was the meeting place of men such as Hogarth, Gravelot, Roubiliac, Hayman, Moser, Fielding, Garrick, Folkes and Paine.

In September 1658 the London Gazette bore notice of Cromwell's death, and Thomas Garway announced 'That excellent and by all physicians approved drink called by Chinean's tcha, and by other nations Tay alias Tea, is sold at the Sultaness Head a cophee house in Sweetings Rents by the Royal Exchange London' (Scott 1965). Two years later Pepys recorded his first cup of tea, and it soon achieved a great popularity in Court circles through Catherine of Braganza (Lancaster 1963); it was a fabulous price at about $£ 3$ a pound in 1666 (though bought in Amsterdam at about three shillings a pound) and even at the end of the seventeenth century cheap tea cost about seven shillings a pound, the equivalent of a labourer's wage for a week. Between the late seventeenth and late eighteenth century tea became the national drink for men and women; 20,000 pounds of tea were imported in 1700, three times this in ten years, 250,000 pounds in 1725 rising to twenty-four million pounds in 1743 ; by the end of the century the duty paid was the equivalent of about two pounds per head of the population and equalled roughly the amount smuggled from France! In 1744 Duncan Forbes the Lord Advocate wrote that the 'meanest labouring man could compass the purchase of tea, and sugar, its inseparable companion, which came to be in the possession of the very poorest housewife where formerly it had been a great rarity, and thereby was at hand to mix with water brandy or rum; tea and punch became thus the diet and debauch of all beer and ale drinkers.' But Lord President Duncan Forbes evidently had no objection to alcohol at his mother's funeral, for when they eventually reached the cemetery they found that they had forgotten the body! In 1757 Jonas Hanway (Drummond and Wilbraham 1958) wrote 'If we drank less tea and used gentle acids for the gums and teeth, particularly sour oranges, though we had less number of French dentists, I fancy this essential part of beauty would be much better preserved. Your very chambermaids have lost their bloom, I suppose by sipping tea-what an army tea and gin has destroyed!' However as a hardened and shameless tea drinker for many years, Dr. Johnson delighted in demolishing Hanway's diatribe; Dr. John Coakley Lettsom also wrote in favour of tea-he was an extremely successful doctor in 1772, reputedly earning 


\section{Warren Harvey}

$£ 12,000$ a year in those days. In contrast, John Wesley gave up tea drinking and also persuaded the Methodists to give up the extravagance, but when he was ill twelve years later his doctor prescribed tea for him, and he had in use a half-gallon tea pot! During this period between the late seventeenth and late eighteenth century when tea became the national drink, it replaced ale for breakfast, and closed the gin houses where men and women got 'drunk for a penny, dead drunk for tuppence'. To offset the loss of revenue on alcohol, tea was heavily taxed, and with the cost of tea only two shillings a pound on the continent compared with sixty shillings a pound in London, there was an enormous inducement to smuggle; so much so that it was estimated that the smugglers, moonrakers, 'gentlemen' or 'free traders' brought in two-thirds of all the tea drunk in the country; little wonder it was that the Riding Officer, Revenue Man or gauger had small chance of stopping the traffic, since public sympathy was mostly with the smugglers; another relevant factor was that even if there was 'baccy for the parson' there was grim butchery of informers; also, inland communications were unimaginably bad with roads little more than cart tracks and dangerous after dark. David Cuthbertson wrote a vivid picture of smuggling tea at this time in Troon, Ayrshire, and the farms, church and local doctor's house used as hideouts look just as innocent today as they did two hundred years ago. The first shop used exclusively for the sale of tea was the Golden Lion next door to Tom's in Devereux Court and owned by Thomas Twining; tea in packets was introduced by John Horniman in 1826. People would 'take the waters' of Bermondsey Spa or Sadlers Wells and there have tea; the next big social change was the opening of the tea gardens in Chelsea, Bayswater, Hampstead, Marylebone, Ranelagh, Coopers Garden (known as Cupid's Garden) over Waterloo Bridge, Vauxhall with its Chinese Pavilions and Rotunda and the Parthenon Gardens.

As the habit of drinking tea spread, so the consumption of sugar rose. In the Middle Ages cane sugar was part of the spice trade from the East to Venice and on to Europe. With the development of sugar colonies in the West Indies and the Atlantic Islands, white sugar candy and the more expensive refined sugars were available not only to the apothecaries, but to chocolate, coffee and tea houses, and those homes which could afford to pay about half a week's wages for a servant per pound of sugar. In 1715 Fred Stare found it necessary to write a vindication of sugar against the charge that this was the cause of scurvy; he quoted the Great Duke of Beaufort who died aged seventy with all teeth firm and viscera of a man aged twenty, in spite of having eaten a pound of sugar a day most of his life.

The English colonies in Barbados and the Leeward Isles were first to develop a sugar industry and with it an export trade to the continent, though unfortunately this was hampered by unwise restrictive trade laws; they were in competition with the French Industry which flourished under wise legislation; since French planters produced at a lower cost and the English market rate was high, smuggling thrived between the English and French colonies, and between Holland, France, Hamburg and England. In 1721 there was an alarming fall in the quantity of sugar exported from England; a London merchant called Drummond gave as one of the causesthe increasing habit of tea and coffee drinking. With the outbreak of the War of Austrian Succession in 1739 there was an immediate rise in the price of sugar-and 


\section{Dental and Social Conditions Connected with St. Bride's Church}

in colonial prosperity, which lasted until the American Revolution. By 1753 there were eighty sugar bakeries in London, and one hundred and twenty in all England and Scotland -each dealing with about two hundred tons a year; in contrast, Hamburg had three hundred and fifty boiling houses at this time. In 1747 Marggraf described how he extracted sugar from skirret, red and white beet; in 1798 Klaproth proved that large scale production was possible, so that Achard was able to erect the first factory in Silesia in 1801. By 1811 Napoleon had inaugurated vast beetroot plantations; a beet factory was started in 1832 in Maldon, Essex, but the project failed. Sugar and slavery in the colonies were closely linked; in 1792 the 'Anti-Saccharites' published this pamphlet 'A family that uses five pounds of sugar per week with the, proportion of rum will, by abstaining from the consumption for twenty-one months, prevent the slavery or murder of one fellow creature! Eight such families in nineteen and a half years will prevent the slavery or murder of one hundred.' In 1840 there was a debate on a Motion by Mr. William Ewart, the Liberal member for Dumfries district, to 'reduce the duty on all foreign sugar from 63s. to $34 \mathrm{~s}$. per hundredweight in support of coffee houses now numbering two thousand and much frequented by persons of the lower rank of society, free from intoxicating drinks, and supplied with newspapers and periodicals highly favourable to the morals of the working class and aiding in the diffusion of knowledge.'

The consumption of sugar in pounds per person per year (Deerr 1950) in the 'United

Kingdom' related to recent figures:

$\begin{array}{rrrr}1700 & 4 & 1700 & 5 \\ 1750 & 8 & 1750 & 40 \\ 1800 & 18 & 1800 & 104 \\ 1850 & 30 & 1850 & 305 \\ 1957 & 110 & 1900 & 1704 \\ & & 1965 & 2500 \text { to 2750 } \\ & & & \\ \text { (Tate \& Lyle) }\end{array}$

Sugar consumption in Great Britain in 1,000 tons per year (Walker 1965):

The average cost of food related to present day prices (Deerr 1960): 1583-1702 1937

\begin{tabular}{lllr}
\multicolumn{4}{c}{1966} \\
$s$. & $d . \quad s$. & $d$. \\
4 & 0 to 10 & 0 \\
3 & 11 & & \\
8 & 0 & & \\
8 & 0 & & \\
1 & 1 to 1 & 11 \\
& $9 \frac{1}{2}$ & & \\
4 & 6 & &
\end{tabular}

In 1798 Malthus wrote his famous Essay on the Principle of Population-arguing that any local or temporary improvement in human living conditions will increase the population faster than the corresponding agricultural developments can increase food supply. At this time and for nearly a thousand years past, the population of Europe had been almost constant with a birthrate of forty per thousand yearly; this is 


\section{Warren Harvey}

probably the maximum of which the human species is capable, and was very necessary because of the ravages of war, famine and disease. However from the middle of the eighteenth century the death rate fell steadily in most European countries, due to the spread of religious tolerance, less civil war, the decline of bubonic plague, and the attenuation of smallpox virus, together with Jenner's vaccination.

Between 1700 and 1820 London's population increased from 67,000 to $1,274,000$. The 'Lowest Class' might have clean sheets three times a year, three to eight persons of varying ages in the same bed and fifteen to twenty in one room. The Fleet Ditch was filled in, but there was still an open gutter or 'kennel' in the middle of the road. Gin was distilled by all and sundry until the Act of 1751 forbade it-by this time an eighth of adult Londoners died of spirit drinking, and Hogarth's 'Gin Lane' was no exaggeration. More people died of gaol fever in 1773 to 1775 than were executed. In the early eighteenth century the only hospitals were St. Bartholomew's, St. Thomas's, Bethlem and Chelsea Royal Hospital; then came Westminster in 1719, Guy's in 1721, St. George's in 1733, the London in 1740 and the Middlesex in 1745, with the first Dispensary for Sick Children in 1769. It was in 1745 that the United Company of Barbers and Surgeons was dissolved; surgery was given a further impetus when William Hunter employed Nicholl's technique of injecting the vascular system and was able to introduce 'winter dissecting as in Paris' at his anatomy school in Covent Garden, which meant a busier time for the body snatchers; by 1823 there were about one thousand medical students in London (Turner 1932)-though five years later the number had dropped to eight hundred because students found better facilities abroad. The efforts made to meet the demand for bodies can be gauged by a statement to the Select Committee on Anatomy in 1828 that in four nights one man organized the exhumation of twenty-three bodies; there were probably two hundred body snatchers working in London, and the price paid for each body varied from six to fourteen guineas.

Dentistry was practised at this time by 'blacksmiths, hair dressers, corn-doctors and innumerable charlatans' (Menzies Campbell 1963), but there were great men to come; in 1766 Ruspini settled in Pall Mall under the patronage of the Dowager Princess of Wales; one of his sons William Ruspini (1780-1812) practised as a dentist at St. Paul's Churchyard.

This was an age when many diseases as we know them today were being recognized and accurately described, some of them being mercifully rare now; for instance, in 1780 at Mark Beaufroy's 'wine factory' there was a vat or tun which held 56,749 gallons and was bigger than the Tun of Heidelburg; lead was used often to 'clear' the wine, and together with cider in lead pipes, caused lead poisoning with much illness, colic and even death.

Sir William Fordyce wrote in 1773 that 'twenty thousand children in London, Westminster and their suburbs were ill at this moment of the Hectic Fever [rickets], with tun bellies, swelled wrists and ankles, or crooked limbs,' and challenged any who doubted him to examine the public charity schools, workhouses and purlieus of St. Giles' and Drury Lane. For centuries, fish oils had been used for sore jointssometimes as an embrocation only and sometimes swallowed as well-by the fishing communities in Iceland, Newfoundland and the Hebrides; in 1772 Kay and Darby 


\section{Dental and Social Conditions Connected with St. Bride's Church}

used cod liver oil in Manchester Infirmary for 'rheumatism', but it was not used extensively for another seventy years; in fact Bland Sutton, the surgeon and anatomist, must have been very enlightened in 1889 to have recommended the addition of crushed bone and cod liver oil to the diets of lions and bears in the London Zoo to prevent rickets or death of the cubs.

As a result of the increase in industry, women were working long hours in grim conditions; infants were seldom breast fed but were reared by parish nurses with supplements of ales, wines, or spirits to keep the peace; wet nurses were expensive in London and about the middle of the eighteenth century infants were fed asses' or cows' milk, using a perforated cow's horn with the finger of a leather glove for a teat; there is one record of only eleven of one hundred and seventy-four infants surviving this life for more than two months. The advent in 1822 of cheap unsupplemented condensed skimmed milk led to even sadder deterioration. In 1847 there were still about twenty-four thousand cows in the Metropolis, but the Lancet reported that it was hard to find any milk without blood or pus in it.

Although conditions for the poor were grim-as described by Charles Dickens and William Cobbett, yet efforts were being made to improve them. In 1833 the Factory Act prohibited child labour under the age of nine-so teeth became very important in the assessment of age; between nine and thirteen, children could only be made to work eight hours a day. In 1845 the country was near revolution, with wages at their lowest level for 100 years, and the food situation desperate because of the potato failure; in May of this year John Delane, Editor of The Times, sent a lawyer as his 'Special Commissioner' to report on the Highland Clearances; the first of these had taken place between 1782 and 1820 and another was raging between 1840 and 1854; John Knox had already reported that between 1763 and 1775 at least twenty thousand had left for the Colonies; but many of those evicted 'took the dreary road over the border' (Prebble 1963). By 1851 half the population of the whole country was urbana situation that had probably not existed before in a great country, at any time in the world's history (Thomson 1965). Food was particularly scarce in London-even oysters were becoming hard to get; there was much adulteration of food-cheese coloured with red lead, alum or plaster of paris or pipeclay in bread. It was rather different for the rich-these were the days of gargantuan five-course dinners with four bottles of wine or port each; André Simon has commented that time was the all important factor-'Given time it is remarkable what a man can do!'

Sanitation was deplorably primitive, with 250,000 cesspools in London-the Government had not dared to publish Playfair's report on the sanitary arrangements in Buckingham Palace. The cholera epidemic of 1847 to 1849 may well have hastened the appointment in 1848 of Sir John Simon as London's first Medical Officer of Health; he instituted enclosed sewers and improved the supply of clean drinking water, which had been so often contaminated from 'cess pools, cow houses and soakings of the graveyards'; in a school in Tooting three hundred out of one thousand children contracted cholera and of these one hundred and eighty died (Thomson 1965).

Although James Lind wrote his Treatise of the Scurvy in 1753 (Major, 1959), the use of lemon juice was not adopted by the Navy until 1796; yet in 1850 Captain Alexander Armstrong (later Medical Director General) spent two and a half years in the Arctic in 


\section{Warren Harvey}

H.M.S. Investigator, and this was the longest period a vessel had stayed immune from scurvy. With this background it seems fantastic that Florence Nightingale had to tell the Commission of Enquiry that in the Crimea scurvy occasioned greater loss of life than any other cause; of twelve hundred sick men who arrived at Scutari on 22 January 1855,85 per cent had acute scurvy; yet, a month before this, twenty thousand pounds of lime juice, with dried potatoes and dried carrots were landed in the base at Balaclava where they stayed for the duration of the war.

But this period of 1696 to 1852 is utterly bewildering in the profusion of so many advances co-existing with quite primitive conditions-less than two hundred and forty years ago (Hemphill 1965) a woman was burned as a witch for turning her daughter into a flying horse! At least two hundred publications appeared containing new facts essential to modern medicine and dentistry; the first part of one of these was a treatise on The Natural History of the Human Teeth, and it enabled John Hunter to marry Ann Home on the proceeds.

This paper started with dentistry, and it is fitting that it should finish with the story of a dentist of this period whose life embodied so many facets of these years, and as on many previous occasions I am indebted to Dr. Menzies Campbell for these details; Theodosius Purland was born in Norwich in 1805; his great grandfather, his grandfather, his father and his uncle were all dentists; his father Marshall Purland, moved to London in 1806 and lived in Red Lion Court, 169 Long Alley, Moorfields, Crown Street, Wilson Street and Finsbury Square where he died in 1844. Dentists then favoured alleys and courts, so that their patients could enter unobserved and have their dental needs treated secretly. In 1816 Thomas Bell paid Marshall Purland forty guineas for instruction 'in the art and mystery of making and fitting artificial teeth' and the following year he was appointed Lecturer on Anatomy and Diseases of the Teeth at Guy's Hospital. Theodosius, though only five feet four inches tall, had decided views and in 1828 he started his own practice in 109 Long Acre, after being trained by his father; this same year he met a lady with whom he fell in love at first sight, proposed and was accepted, all within half an hour; they were married on 24 January 1829 in St. Bride's Church, Fleet Street. They lived in Maddox Street, Princes Street, Hanover Square and Mortimer Street, Cavendish Square. He wrote works on conservative dentistry and criticized the Crawcour brothers for filling teeth with amalgam instead of gold. In 1844 he advocated a College of Dentists and this was later founded on 22 September 1856 in the London Tavern, and subsequently joined with the Odontological Society of Great Britain. In 1858 Parliament legalized the granting of a licentiate in Dental Surgery by the Royal College of Surgeons. Theodosius Purland was a man of wide interests-five times he accompanied Charles Green in a balloon from Vauxhall Gardens. He was a member of the London Committee which in 1847 purchased Shakespeare's home to preserve it for the nation, and was present in 1859 by invitation at the re-interment of the remains of John Hunter in Westminster Abbey. He had an elaborate aviary at his home and compiled numerous scrap books on a wide variety of topics. Purland believed that technical perfection alone would not advance the status and prestige of dentistry, but that there was an additional and special need for culture, erudition and an acquaintance with the arts and literature. This need is as great today as it was one hundred and twenty years ago, and seems to 


\section{Dental and Social Conditions Connected with St. Bride's Church}

be shown in so many ways by these links between St. Bride's and dentistry.

\section{ACKNOWLEDGEMIENTS}

I have had much generous help from many people, especially from the Reverend Dewi Morgan. I would like to thank Professor T. C. White-the Director of Dental Education, and the University of Glasgow for permission and encouragement to carry out this work. I have had much help from Dr. and Mrs. J. Menzies Campbell and Dr. and Mrs. Ian Porter, and they have greatly reduced the imperfections in the text. Miss D. F. Hollingsworth of the Ministry of Agriculture, Fisheries and Food, and Miss V. White of the Antique Collector very kindly read through the draft of this paper. I have also had much help and kindness from Professor James Aitchison. I would also like to thank Mr. Ian Murray and Miss Huntley for so much help with the photographs, Miss Carson and her staff in the X-ray Department, and Miss J. McCulloch for her secretarial help. I would also like to thank Professor George Nixon for operating so smoothly as 'entremetteur' with Stewarts and Lloyds Ltd., of Glasgow who very kindly carried out the metallurgical investigations.

\section{BIBLIOGRAPHY}

Bell, W. G., The Great Plague, London, Guild of St. Bride, Patina Press, 1957.

Brothwel,, D., 'Teeth in earlier human populations', Proc. nutr. Soc., 1959, $18,59$.

Camprell, J. Menzies, Dentistry Then and Now, Glasgow, Pickering and Inglis, 1963.

Clark, Henry B., Practical Oral Surgery, London, Henry Kimpton, 1959.

CrAIG, H. N., Some Notes on the Cathedral of St. Brigid, Dublin, Kildare, Healy, 1931.

Cuthibertson, DAvid, The Smugglers of Troon, Ardrossan, Arthur Guthrie; Edinburgh and Glasgow, John Menzies, [c. 1930].

Davidson, SiR S., Meiklejorn, A. P., and Passmore, R., Human Nutrition and Dietetics, Edinburgh and London, E. \& S. Livingstone, 1959.

DekrR, NoEl, The History of Sugar, London, Chapman and Hall, 1950.

Drummond, J. C., Wilbraham, ANNe, and Hollingsworth, D. F., The Englishman's Food, London, Jonathan Cape, 1958 (2nd ed., 1964).

HARDWICK, J. L., 'The incidence and distribution of caries throughout the ages in relation to the Englishman's diet', Brit. dent. J., 1960, 108, 1.

Harrison, R. J., 'Bones, teeth, and identification', Proc. R. Instn Gt. Br., 1963, 39, 179.

HARVEY, WARREN, and ROBb, RICHARD A., The Mandibular Foramen in Relation to Anaesthesia of the Inferior Alveolar Nerve, unpublished thesis.

Hzimy, Mahmoud, 'The relation of the inferior dental nerve to the solid and semisolid tumours of the mandible', Egypt. dent. J., 1958, 4 (3), 36.

Hemphil, R. E., Proc. R. Soc. Med., 1965, 58, 2.

London Survey Committee, Commemorative Volume on the Destroyed Church of St. Bride, Fleet Street, 15th monograph, London, British Museum, 1944.

Major, RalPH H., Classic Descriptions of Disease, Springfield, Illinois, C. Thomas, 1959, 3rd. ed.

Prebble, JoHn, The Highland Clearances, London, Secker and Warburg, 1963.

REDPATH, WIILIAM, Fleet Street's Church Restored, 1940-1957, London, Guild of St. Bride, Patina Press, 1959.

Scott Park, S. D., Consultant Radiologist, Western Infirmary, Glasgow, personal communication, 1965.

SPEnCER, Alfred, Memoirs of William Hickey, Vol. 1, 1749-1775, London, Hurst and Blackett, 1948, 10th ed.

STERL, F. L. D., 'Investigation of the skeletal remains of a known population', Medicine, Science and the Law, October, 1960.

Stone, JoNATHAN, 'The background to eighteenth century English silver', Antique Collector, August, 1965.

Thomson, D., 'Change in epidemiology and preventive medicine', Proc. R. Soc. Med., $1965,58,831$.

Tоugh, J., Regional Consultant in Plastic and Maxillo-Facial Surgery, Glasgow, personal communication, 1965.

TURNer, CrCIL Howard, The Inhumanists, London, Alexander Ouseley, 1932.

WALKER, Hugh B., John Walker \& Co. Ltd., personal communication, December, 1965. 